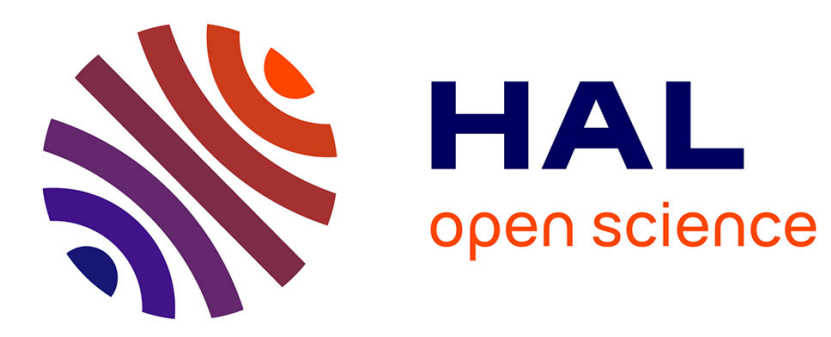

\title{
Reconstitution of debris flow dynamics on a forested cone combining dendrogeomorphology and diachronic orthophotography analysis (Mont Granier, Chartreuse massif, French Prealps)
}

Johann Blanpied, Laurent Astrade, Estelle Ployon

\section{To cite this version:}

Johann Blanpied, Laurent Astrade, Estelle Ployon. Reconstitution of debris flow dynamics on a forested cone combining dendrogeomorphology and diachronic orthophotography analysis (Mont Granier, Chartreuse massif, French Prealps). Géomorphologie : relief, processus, environnement, 2017, 23 (3), pp. 253-263. 10.4000/geomorphologie.11814 . hal-01635796

\author{
HAL Id: hal-01635796 \\ https://hal.science/hal-01635796
}

Submitted on 4 May 2020

HAL is a multi-disciplinary open access archive for the deposit and dissemination of scientific research documents, whether they are published or not. The documents may come from teaching and research institutions in France or abroad, or from public or private research centers.
L'archive ouverte pluridisciplinaire HAL, est destinée au dépôt et à la diffusion de documents scientifiques de niveau recherche, publiés ou non, émanant des établissements d'enseignement et de recherche français ou étrangers, des laboratoires publics ou privés. 


\section{Géomorphologie : relief, processus,}

environnement

vol. $23-n^{\circ} 3 \mid 2017$

Biogéomorphologie

\section{Reconstitution of debris flow dynamics on a forested cone combining dendrogeomorphology and diachronic orthophotography analysis (Mont Granier, Chartreuse massif, French Prealps)}

Reconstitution de la dynamique de lave torrentielle sur un cône forestier combinant dendrogéomorphologie et analyse diachronique d'orthophotographie (Mont Granier, Massif de la Chartreuse, Préalpes)

Johann Blanpied, Laurent Astrade and Estelle Ployon

\section{(2) OpenEdition}

Electronic version

URL: http://journals.openedition.org/geomorphologie/11814

DOI: 10.4000/geomorphologie. 11814

ISSN: 1957-777X

Publisher

Groupe français de géomorphologie

Printed version

Date of publication: 24 October 2017

Number of pages: $253-263$

ISBN: 978-2-913282-77-3

ISSN: 1266-5304

Electronic reference

Johann Blanpied, Laurent Astrade and Estelle Ployon, « Reconstitution of debris flow dynamics on a forested cone combining dendrogeomorphology and diachronic orthophotography analysis (Mont Granier, Chartreuse massif, French Prealps) », Géomorphologie : relief, processus, environnement [Online], vol. $23-n^{\circ} 3$ | 2017, Online since 02 October 2017, connection on 28 April 2019. URL : http:// journals.openedition.org/geomorphologie/11814; DOI : 10.4000/geomorphologie.11814 


\section{Reconstitution of debris flow dynamics on a forested cone combining dendrogeomorphology and diachronic orthophotography analysis (Mont Granier, Chartreuse massif, French Prealps)}

\section{Reconstitution de la dynamique de lave torrentielle sur un cône forestier combinant dendro- géomorphologie et analyse diachronique d'orthophotographie (Mont Granier, Massif de la Chartreuse, Préalpes)}

Johann Blanpied ${ }^{\star a, b}$, Laurent Astrade ${ }^{a}$, Estelle Ployon a

a EDYTEM UMR 5204 CNRS, Université Savoie Mont Blanc - 5 bd de la mer Caspienne, 73376 Chambéry, France. ${ }^{\mathrm{b}}$ GEODE UMR 5602 CNRS, Université Jean Jaurès - 5 allée Antonio Machado, 31058 Toulouse, France.

ARTICLE INFORMATION

Received 20 march 2017.

Received in revised form 15 september 2017.

Accepted 29 september 2017.

${ }^{*}$ Corresponding author. Tel : +33 5615036 26; E-mail adresses:

blanpied.johann@gmail.com (J. Blanpied)

laurent.astrade@univ-smb.fr (L. Astrade)

estelle.ployon@univ-smb.fr (E. Ployon)

\begin{abstract}
The past debris flow dynamics of the Ravin du Diable are analyzed by an integrative approach based on dendrogeomorphological methods coupling with diachronic orthophotography analysis. The aim is to reconstruct (i) both frequency and spatial extent of the recent debris flow activity, (ii) key debris flows on the cone dynamic and then (iii) the global torrential dynamics on a depositional forested cone in the French Prealps. Due to one of the most important landslide in Europe occurred in 1248, the Ravin du Diable is part of a very young and steep highly active catchment of 16 ha. Situated on the north face of the Mont Granier, part of Chartreuse Massif, this catchment is now well known for being an active debris flow corridor. Based on a dendrogeomorphological analysis, 315 growth disturbances from 189 trees (68\% of resinous trees: Picea abies, Abies alba and 32\% of broadleaved trees: Fraxinus excelsior, Alnus Incana) allowed a reconstitution of 14 events since 1968 including 7 unknowns debris flows in the historical archives and an estimation of 21 debris flows since 1915. Coupling with dendrogeomorphology, 13 orthophotographies since 1948 revealed channels activity, channels mobility, and different stages of the forest stand re-colonization. As a result obtained from this integrative approach, the spatial minimum extent of every major debris flows was mapped. Furthermore, 4 spatial morphological changing periods of the depositional cone dynamics were identified, resulting from debris flows intense activity.
\end{abstract}

Keywords: debris flow, dendrogeomorphology, depositional cone, orthophotography, French Prealps.

\section{RÉSUMÉ}

La dynamique passée des laves torrentielles du torrent du Ravin du Diable est analysée à partir d'une approche intégrative basée sur le couplage entre une analyse dendrogéomorphologique et une analyse diachronique d'orthophotographie. Lobjectif principal est de reconstituer lactivité spatio-temporelle des laves torrentielles puis de comprendre la dynamique passée d'un cône végétalisé dans les Préalpes françaises. Ce torrent, désormais bien connu comme couloir producteur de laves torrentielles, incise les gorges de la fameuse paroi rocheuse du Mont Granier, mise à nu lors du plus important écroulement d'Europe en 1248, et draine un bassin versant très pentu d'environ 16 ha. Les analyses dendrogéomorphologiques réalisées sur 189 arbres du cône de déjection (68\% de résineux: Picea abies, Abies alba et $32 \%$ de feuillus: Fraxinus excelsior, Alnus Incana) ont permis d'identifier 315 perturbations de croissance. 14 laves torrentielles depuis 1968 dont 7 inconnues dans les archives du Service de Restauration des Terrains en Montagne ont été reconstituées et 21 laves torrentielles depuis 1915 estimées. Par ailleurs, l'analyse diachronique d’un jeu de 13 orthophotographies révèle la mobilité et l'activité des différents chenaux depuis 1948 ainsi que les différentes étapes de recolonisation végétale du site. L'extension minimale des laves torrentielles majeures passées a donc pu être cartographiée et 4 périodes de changements morphologiques du cône de déjection identifiées.

Mots clés : lave torrentielle, dendrogéomorphologie, cône de déjection torrentiel, orthophotographie, Préalpes françaises.

\section{Introduction}

Depositional cones are widespread features in the Alps and Prealps. Those ecosystems represent a memory of hydrogeomorphic processes occurring in their catchment (Stoffel and Wilford, 2012) where natural conservation and hazard management must be reconciling with urban planning. Nowadays natural hazard occurrence forecasting such as avalanches or debris flows is still complicated but the spatial extent can be estimated. Debris flows are parts of the most common processes in the Alps and Prealps, they represent a major threat to transportation corridors and buildings or even the loss of lives (Bollschweiller et al., 2008). Debris flows are surges of saturated non-plastic debris traveling steep channels at a range of 2-20 m.s. ${ }^{-1}$ with sediment concentrations generally 
higher than $50 \%$ by volume (Hungr et al., 2001; Jakob and Jordan, 2001). Lacks in historical archives about those phenomena in term of intensity and spatial extent (Corona et al., 2010) bring to light an enhancement in knowledge to improve zonation and mitigation of related hazard. It is also necessary to understand the role of debris flow supply condition and meteorological event as triggering factors of debris flows (Bovis and Jakob, 1999).

On forested depositional cones, debris flows impacted trees. In this case, dendrogeomorphology becomes an accurate technique in our integrative approach to understand torrential dynamics. From dendrochronology, dendrogeomorphology is a technique of reconstructing and dating past geomorphic processes through growth disturbances contained in tree rings (Alestalo, 1971). The aim is to distinguish the difference between climatic fluctuation and geomorphic process in tree rings. Since Alestalo's work, dendrogeomorphology had widely improved to each process among which landslides (Stefanini, 2004; Lopez Saez et al., 2011), avalanches (Bryant et al., 1989; Corona et al., 2010), floods (Astrade and Bégin, 1997) and debris flows. Over the past decades geomorphic work on debris flows has been well documented by dendrogeomorphological methods with several studies focusing on frequency (Hupp et al., 1984; Bollschweiler and Stoffel, 2010), or both on frequency and magnitude (May and Gresswell, 2004; Stoffel et al., 2005; Stoffel, 2010), then on a spatio-temporal reconstitution of past events (Bollschweiler et al., 2007). Furthermore, tree ring analysis was also used with a Light Detecting and Ranging (Lopez-Saez et al., 2011), with orthophotographies (Procter et al., 2011, 2012) and broadleaved trees (Arbellay, 2010a, 2010b) to increase resolution of a spatio-temporal reconstruction of past debris flows activity. The study of Procter et al. (2011) provided the first regional investigation of debris flow activity in the Austrian Alps using dendrogeomorphology. Dendrogeomorphic reconstructions of past
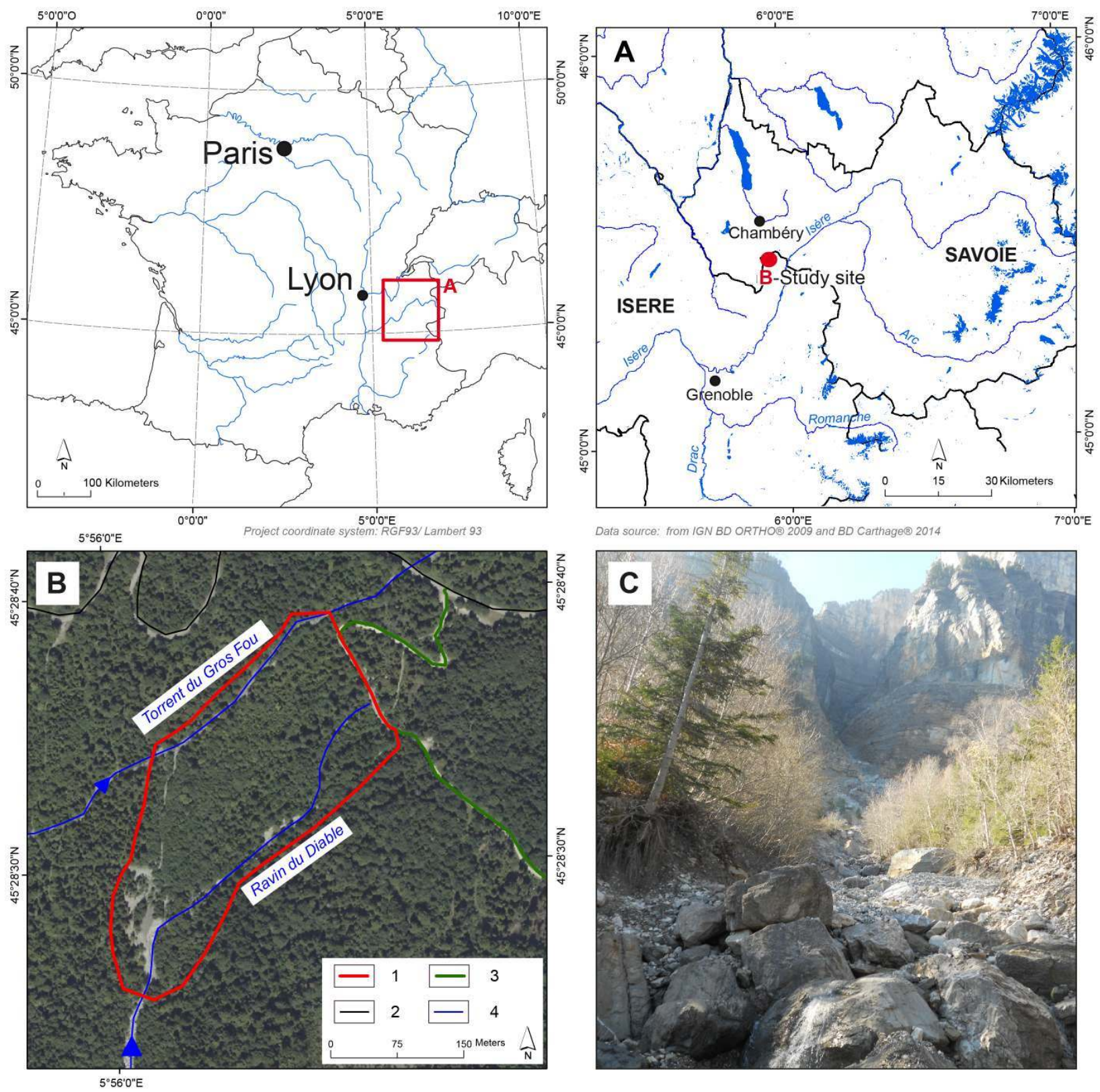

Fig. 1 - (A) Location map of the study site. (B) Sketch map of the study site. (C) Photography of the Ravin du Diable channel from the Mont Granier.

1. Study area; 2. Road; 3. Forestry road; 4 . Drainage network.

Fig. 1 - (A) Carte de localisation du site d'étude. (B) Schéma du site d'étude: (C) Photographie du chenal du Ravin du Diable issu du Mont Granier.

1. Zone d'étude; 2. Route départementale; 3. Piste forestière; 4. Réseau hydrographique. 
debris flow activity have abundantly been studied in North America (Hupp et al., 1984; May and Gresswell, 2004) or even in the Swiss Alps (Mayer et al., 2010; Stoffel et al., 2005; Stoffel and Beniston, 2006; Stoffel et al., 2008; Stoffel, 2010) but are largely missing in the French Alps. In France, Corona et al. (2011) worked on a validation of a dendrogeomorphological method for quantifying erosion rates on black marls (Draix, Alpes de Haute-Provence) and LopezSaez et al. (2011) reconstructed debris flow activity in abandoned channels in the Manival torrent (Massif de la Chartreuse).

It is therefore the purpose of this study to realize an approach that integrating (i) dendrogeomorphology on resinous and broadleaved trees with orthophotography interpretations, to reconstruct (ii) the spatio-temporal debris flows activity, and (iii) dynamics of the partly forested cone.

Debris flows in Ravin du Diable is a recent hazard. During the last decade, a few debris flows spread on the mountain massif road access. Management authorities were recently aware about this risk and required our study. To explain current context dynamics, an integrative approach was set up to reconstruct spatio-temporal dynamics of debris flows and the cone over a recent past.

\section{Study area}

The Ravin du Diable torrent flows down from the north face of the Mont Granier situated in the French Prealps (Isère department, $45^{\circ} 28^{\prime} \mathrm{N}, 5^{\circ} 56^{\prime} \mathrm{E}, 1,933 \mathrm{~m}$ alt.) (fig. 1). It is part of the north of Chartreuse Massif about $10 \mathrm{~km}$ south of Chambéry partially included in the Natural Reserve of the Hauts de Chartreuse. The current landscape with the $700 \mathrm{~m}$ rockwall appeared after one of the biggest landslide in Europe in 1248, lost at least 1,000 victims. The Ravin du Diable (fig. 1C) which cracks the rockwall from $1,850 \mathrm{~m}$ to $1,200 \mathrm{~m}$ with an average slope of $57^{\circ}$ and the Gros Fou torrent, alimented by a spring from the western part of talus below the rockwall, are both tributaries and composed the Glacières torrent. Ravin du Diable debris flows are usually triggered by summer thunderstorms with sudden precipitations but depends on the upper channel sediment storage. This rockwall is composed by limestones and marls of the Urgonian, Hauterivian and Valanginian from the lower cretaceous age.

During the last decades, Ravin du Diable built a depositional cone and flowed down the face and cone by an axial channel to the confluence with the Gros Fou torrent. Actually, flows and debris flows spreads on the forest stand and the forestry road by the northeastern channel before the creation of an anthropogenic channel which bring it back to the confluence. From 1,050 m for the apex to $850 \mathrm{~m}$, the depositional cone of 7 ha is widely forested by impacted resinous and broadleaved trees (Picea abies, Abies alba, Fraxinus excelsior, Alnus incana, Fagus sylvatica, Sorbus aria, Acer pseudoplatanus, etc.). Mean annual precipitation is about $1,152 \mathrm{~mm}$ on the period 1971-2000 at the nearby Chapareillan station but extreme daily precipitations occur more frequently in summer National Forest Office (ONF) archives listed 10 debris flows since 1900 , they usually flowed during summer rainstorms.

Historically debris flows sometimes impacted the access road to the Granier pass. Since the last decade, the axial channel's disconnection brought more and more sediment deposits downstream on the forestry road, the tourist carpark, and actually on the main road. The awareness of authorities allowed our applied methodology to requirement on activity and mobility reconstruction for a better mitigation.

\section{Methods}

\subsection{Orthophotography analysis}

This research focused on a time series of twelve orthophotographies derived from aerial photographs of the French National Geographic Institute (2013, 2009, 2006, 2003, 2001, 1998, 1996, 1990, 1982, 1972, 1956 and 1948). ArcMap 9.3 Software (ESRI) has been used to identify significant features of dynamics on the depositional cone such as active channel width, incision area and representative active deposits materials. On past orthophotographies, an active channel is defined as a corridor sufficiently wide, straight and devoid of vegetation. It gave an indication of the basic dynamic of the cone (fig. 2) and improved the precision of the dynamic description (Procter et al., 2012) to get a better sampling strategy.
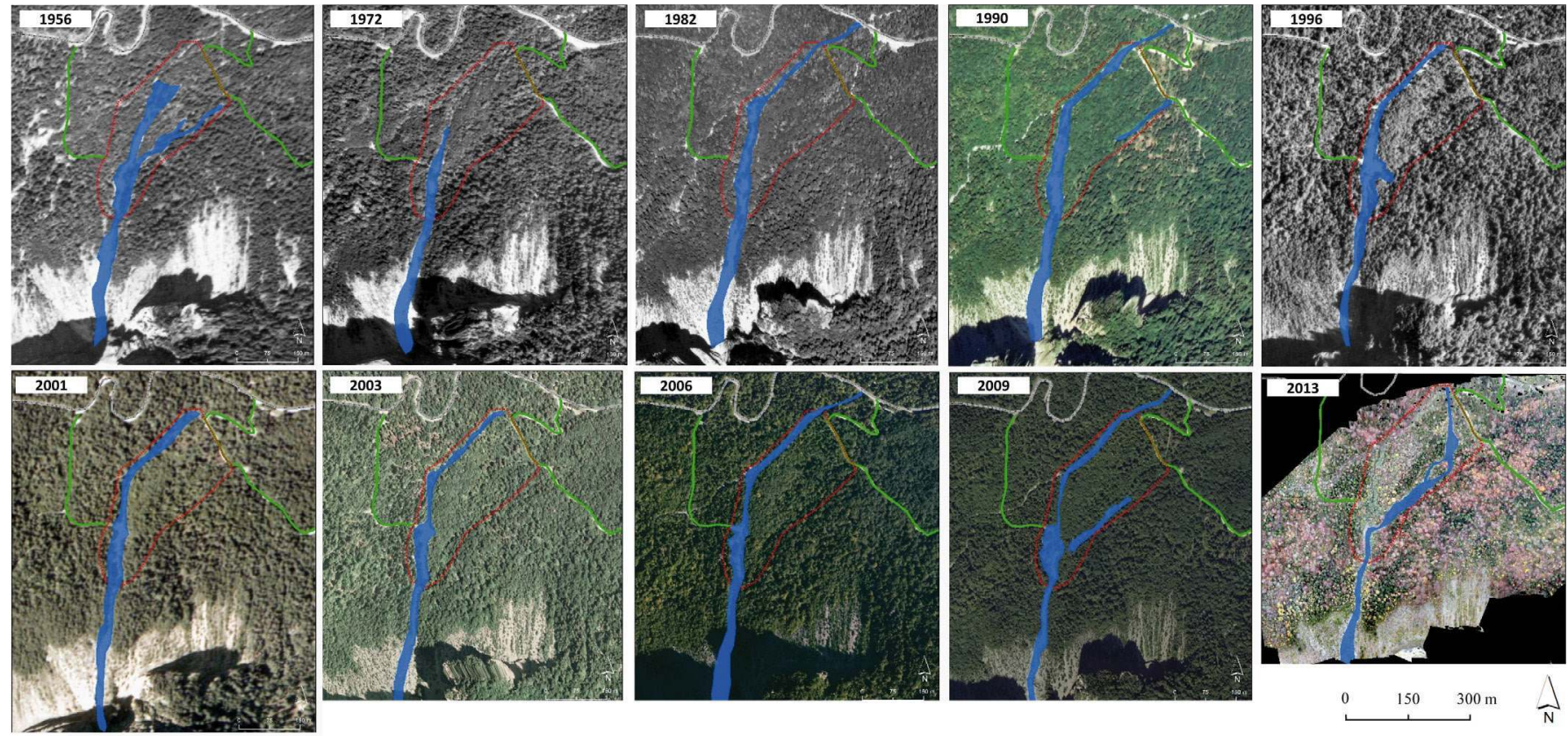

Fig. 2 - Carte de l'évolution de la largeur des chenaux actifs entre 1956 et

Fig. 2 - Map of the widening evolution of active channels between 1956 and 2013.
2013. 


\subsection{Geomorphic mapping}

A detailed geomorphic map (fig. 3) was established representing all features associated with past debris flow activity: lobes, levees, abandoned and active channels. Between the two main channels, sediment deposits are covered by moss and an old forest stand. De facto, there weren't any possibilities to distinguish dynamics features and impacted trees. Three massive blocks from the Mont Granier rockwall were indicated on the map. These features were georeferenced and a geodatabase was built to help for the sampling strategy of trees growing in the deposits and obviously impacted by previous debris flows.

\subsection{Dendrogeomorphic analysis}

Dendrogeomorphological analyses are based on the "processevent-response" concept as defined by Shroder $(1978,1980)$ and re-defined by Astrade et al. (2012). The "process" is the geomorphic agents, such as debris flow, landslide, rockfall, avalanche or anthropogenic variation of the environment. The "event" corresponds to the geomorphic process which impacts a tree and causes disturbances or mechanical damages by engaging a growth "response".

\subsubsection{Sampling strategy}

Field protocol investigation was inspired by Bollschweiler and Stoffel (2007) and Arbellay et al. (2010a). Additional references were collected for each tree sampled included: tree species, tree position in relation with debris flow deposits, photography, sort and position of the visible disturbances (tilted, buried or injured stem), increment core or cross wedge and cross section, and georeferencing of each tree.

Based on the geomorphic map and outer inspection of the stem surface, resinous trees with morphological visible disturbances due to past debris flow were sampled in priority and then broadleaved trees. In the Natural Reserve (upper part of the cone), we weren't allow to sample cross section consequently at least two increment cores were extracted per tree using an increment borer. Usually one was sampled in the assumed flow direction and the other on the opposite side of the trunk, they had to be always perpendicular to the tree following sampling methods of Astrade et al. (2012).

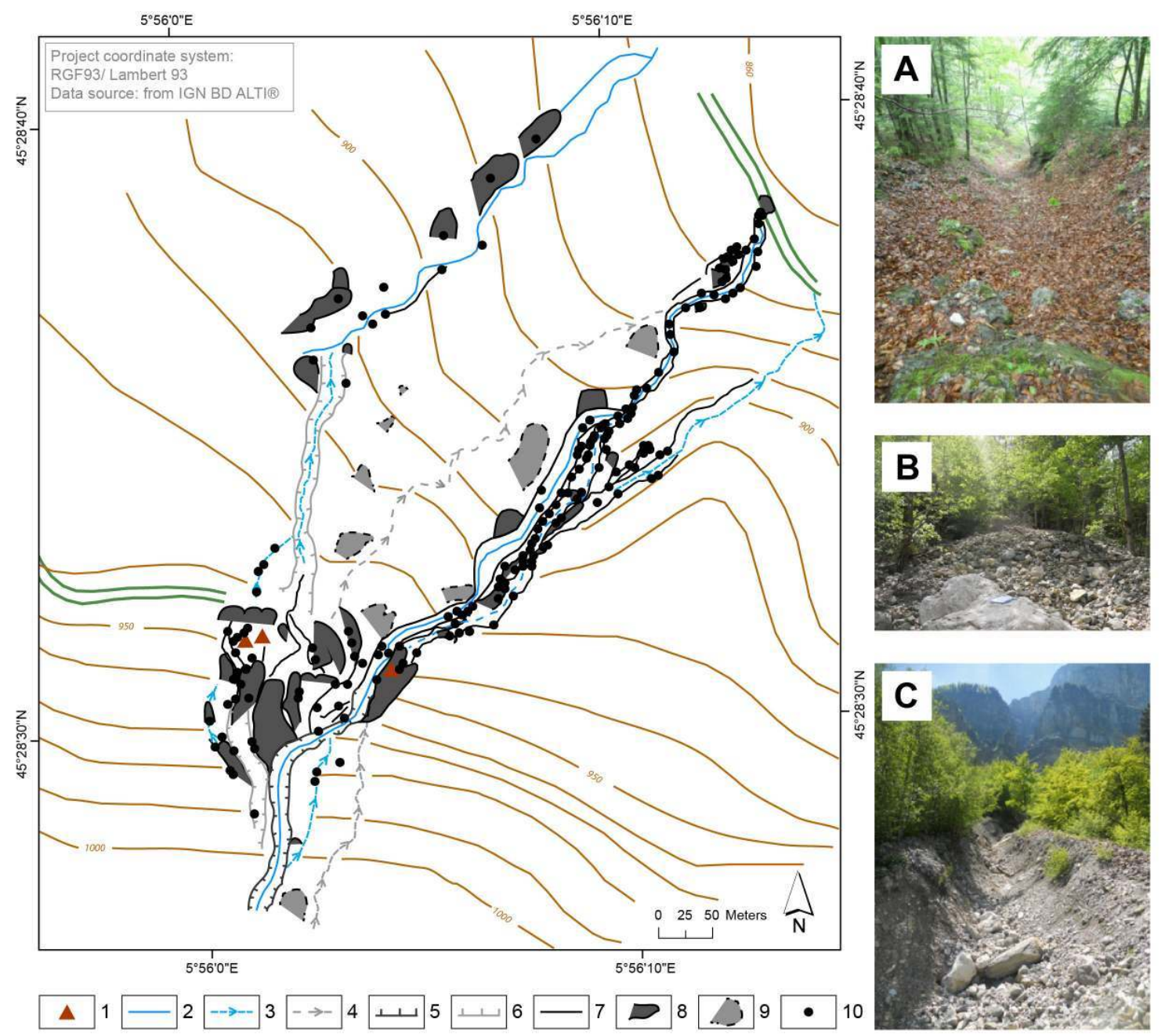

Fig. 3 - Detailed geomorphic map (scale: 1:3,000) of recent and past deposits forms identified on the cone with sampled trees.

1. Massive block; 2. Active channel; 3. Secondary channel; 4. Inactive channel; 5. Channel incision; 6. Inactive channel incision; 7. Lateral levee; 8. Recent debris flow lobe; 9. Past debris flow lobe; 10. Sampled trees. For example, photography (A) represents an inactive channel, photography (B) a debris flow lobe and photography (C) an active debris flow channel.
Fig. 3 - Carte géomorphologique détaillée (échelle : $1: 3$ 000) des dépôts torrentiels et des arbres échantillonnés sur le cône de déjection.

1. Bloc écroulé; 2. Chenal actif; 3. Chenal secondaire; 4. Chenal inactif; 5. Incision $d u$ chenal ; 6 . Incision passée d'un chenal ; 7. Levée latérale ; 8 . Lobe récent de lave torrentielle; 9. Lobe de lave torrentielle passée; 10. Arbres échantillonnés. Par exemple, la photographie (A) représente un chenal inactif, la photographie (B) le lobe d'une lave torrentielle, la photographie $(C)$ un couloir à laves torrentielles actif. 
In addition, one wedge per injury was extracted. Downward, outside of the Natural Reserve, cross sections and increments cores were sampled. But in order to preserve as much tree ring information as possible, a link was established between the kind of visible scars, orientation and sample height. Scared and tilted trees were sampled at disturbance height whereas buried trees samples were extracted next the stem base. In total, 189 trees were sampled (fig. 3), included 67 Picea abies, 59 Abies alba, 31 Fraxinus excelsior, 20 Alnus incana, 7 Fagus sylvatica and 5 others unidentified broadleaved trees (tab. 1).

Tab. 1 - Statistic distribution of sample type, disturbance morphological type and sample specie.

Tab. 1 - Distribution statistique du type d'échantillonnage, du type de perturbation morphologique et d'espèce échantillonnée.

\begin{tabular}{lcc}
\hline Sampled species & Sample number & $\%$ \\
\hline Picea abies & 67 & $36 \%$ \\
\hline Abies alba & 59 & $32 \%$ \\
\hline Fraxinus excelsior & 31 & $17 \%$ \\
\hline Alnus incana & 20 & $11 \%$ \\
\hline Fagus sylvatica & 7 & $4 \%$ \\
\hline Others & 6 & $4 \%$ \\
\hline Total & 189 & $100 \%$ \\
\hline Sampled types & Sample number & $\%$ \\
\hline Cross section & 144 & $65 \%$ \\
\hline Increment core & 58 & $26 \%$ \\
\hline Injured wedge & 20 & $9 \%$ \\
\hline Total & 222 & $100 \%$ \\
\hline $\begin{array}{c}\text { Disturbance } \\
\text { morphological types }\end{array}$ & Disturbance number & $\%$ \\
\hline Injured tree & 110 & $33 \%$ \\
\hline Tilted stem & 109 & $33 \%$ \\
\hline Burried stem & 103 & $31 \%$ \\
\hline Decapitated tree & 9 & $3 \%$ \\
\hline Total & 331 & $100 \%$ \\
\hline & & \\
\hline 3.2 & & \\
\hline
\end{tabular}

\subsubsection{Laboratory methods}

Laboratory works on the 222 samples partly followed standardized dendrogeomorphologic procedure described in Stoffel and Bollschweiler (2008). Individual preparation included sample mounting on a cardboard support, drying and a surface sanding up to grit size 200. Afterwards each cardboard slab containing about 50 increments core or 20 cross sections were scanned at high resolution (1,200 dpi). The annual measurement of tree ring widths was done using CooRecorder Software and downlowded to CDendro Software for growth curve crossdating starting from the youngest ring. In this study, an intra-annual dating precision with tangential rows of traumatic resin ducts wasn't necessary.

All samples were visually inspected to identify relevant growth disturbances listed (fig. 4): (i) production of callus tissue. Impacts of debris flows locally destroyed cambium, therefore cells will overgrow the injury from its edges and lead to the complete closure of the scar (fig. 4A, D); (ii) production of compression wood (resinous) or tension wood (broadleaved). After a debris flow, a tilted tree will always try to regain its vertical position (tropism) to get light. Tree ring response is to produce an asymmetric growth. On the upslope side, compression wood will be produced with larger and darker (reddish) rings than narrow annual rings on the opposite side. Whereas broadleaved trees will react with the formation of tension wood which allowed a tree mechanic stability (Arbellay et al., 2010a; Astrade et al., 2012; Stoffel et al., 2013) (fig. 4C, F); (iii) an abrupt growth decrease after stem burial or root exposure due to the lack of water and nutrients (Arbellay et al., 2010a) (fig. 4B, E); (iv) an abrupt growth increase for survivor trees after the elimination of neighboring trees. Competition to nutrients, water and especially to the light will be lower, survivor trees will have a significant growth response (Astrade et al., 2012).

For the two last one case, without a tree ring reference chronology, an abrupt growth disturbance from debris flow had to marked a decrease or increase in annual ring width for at least 2 consecutive years (Arbellay et al., 2010a) and the first narrow ring had to be $50 \%$ less wide than the previous ring (Stoffel and Bollschweiller, 2008). All the growth disturbances were listed in an ArcGis geodatabase.

In order to validate our dendrogeomorphic approach and to avoid bias due to disturbances such as parasites or other locally geomorphic process, the detection threshold of debris flows were applied, following Lopez Saez et al. (2011) and Lopez Saez and Corona (2015) who defined it as:

$$
\mathrm{It}=\left(\sum(\mathrm{Rt}) / \sum(\mathrm{At})\right) \star 100
$$

where It represents the index of growth disturbance frequency per year, $\mathrm{R}$ represents the number of trees with a growth disturbance and $\mathrm{A}$ as the total number of living tree during this year.

Lopez and Corona (2015) set the threshold at $5 \%$ with a minimum number of 5 growth disturbances (Lopez Saez et al., 2011) to identify a debris flow event. Coupling to this two requirements, a spatial analysis of affected trees per year is also required (Bollschweiller and Stoffel, 2007). Maps of affected trees spatial distribution were created and assessed the minimum frequency and spatial extent of debris flow activity. The age of each tree, were included to the database to build a map of the age structure.
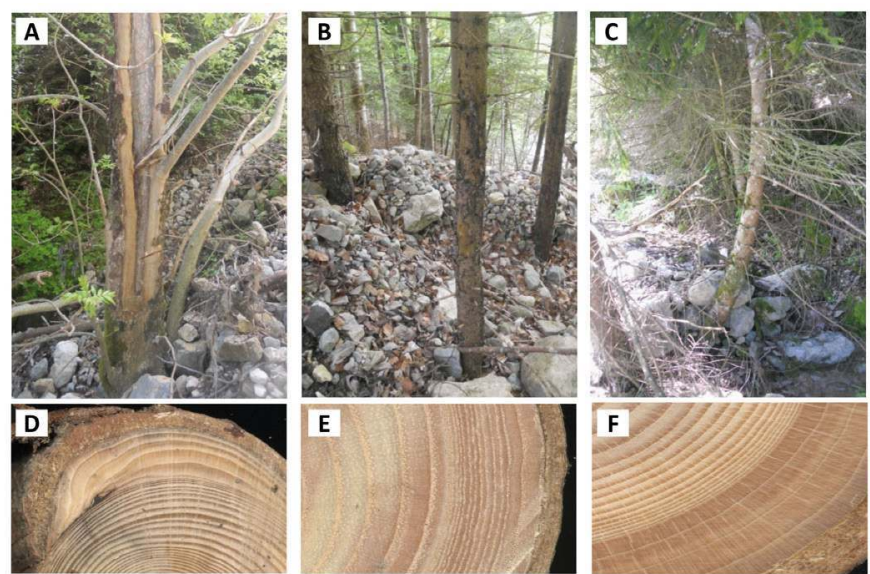

Fig. 4 - Types of affected trees and associated growth disturbances.

(A) Injured tree with production of callus tissue (D), (B) buried stem base and his associated abrupt growth decrease (E), (C) tilted tree and his formation of compression $\operatorname{wood}(\mathrm{F})$.

Fig. 4- Types d'impacts morphologiques et perturbation de croissance associée. (A) Arbre blessé avec production de tissu calleux (D), (B) Base du tronc enfouie et réduction de croissance des cernes associés (E), (C) Arbre courbé et formation de bois de compression $(F)$. 


\subsubsection{Determination of re-vegetalised area and last debris flow dating}

Currently abandoned channel and areas with less impacted broadleaved trees were identified on the depositional cone. Therefore, germination ages of trees growing on a debris flow features such as levees and lobes can be used to estimate "the minimum age dating" (Stoffel and Bollschweiler, 2008). Several trees were sampled by crosssections to get the germination date of the oldest tree. It allowed to assess the minimum time elapsed since the last devastating debris flow and to determine the stabilization of lobes and levees (Stoffel et al., 2008; Bollschweiler et al., 2008). A waiting period of about 6 months called "ecesis interval" (Mc Carthy and Luckmann, 1993; Astrade et al., 2012) was included corresponding to the time elapsed between the clearing event and the re-conolization due to the climatic condition, the nature of the soil, etc. This approach gave further informations on spatio-temporal dynamics of past debris flow in these areas where dendrogeomorphic methods were limited.

\section{Results}

\subsection{Geomorphic map and age structure}

An area of 8 ha was mapped at 1:3,000 scale. 2 inactive channels, 4 secondary channels (liquid flow only during rainstorms periods) and 1 active channel flow were identified. On the upper part of the cone, biggest lobes and levees are concentrated and the active channel deeply incised on its own deposits.

The spatial sampling distribution was similar to those of impacted trees mainly concentrated on the Southeast part. The average of the 189 selected trees is 38.62 years. Figure 5 represents the forest stand age structure which allowed to identify a dynamic of vegetal recolonization. The concentration of older resinous trees is situated on the western part buried in recent sediment deposits. Young broadleaved trees grew downward close to the forest exploitation road, between the northern part and the past confluence. This young forest stand had an average age of 11 or 12 years in 2013 corresponding to a re-vegetation from 2001, whereas the forest stand near the confluence was younger around 2010 (fig 5). These observations and assessments of the age of young forest stand allowed datation of the last debris flow activity in this area (Bollschweiler et al., 2008).

\subsection{Growth disturbance and dating past debris flow events}

Tree ring analysis of the 144 cross sections, 58 increment cores and 20 wedges resulted in 315 growth disturbances. Signature of past debris flows events were identified in trees through 128 injuries, 105 compression or tension woods, 65 abrupt decreases and 17 abrupt increases of tree rings growth. Statistic in Table 1 showed a relationship between the kind of growth disturbance and tree species. $68 \%$ of sampled trees were resinous (36\% Picea abies, $32 \%$ Abies alba) represented $80 \%$ total growth disturbances while $32 \%$ of broadleaved trees represented only $20 \%$ (whose 12\% from Fraxinus Excelsior).

In total dendrogeomorphological analysis allowed recognition of 14 debris flows since 1968 (fig. 6). If we selected only the It threshold of $5 \%$ with a logical spatial distribution of impacted trees per year, we could estimate 21 debris flows since 1915. Figure 6 provides a frequency reconstruction of debris flow activity. 1982, 1991, 1992, 2001 events related in the historical archives were confirmed and spatially specified. Since 1968, 7 unknowns debris flows were also identified. Considering a period of 98 years (1915-2013), the

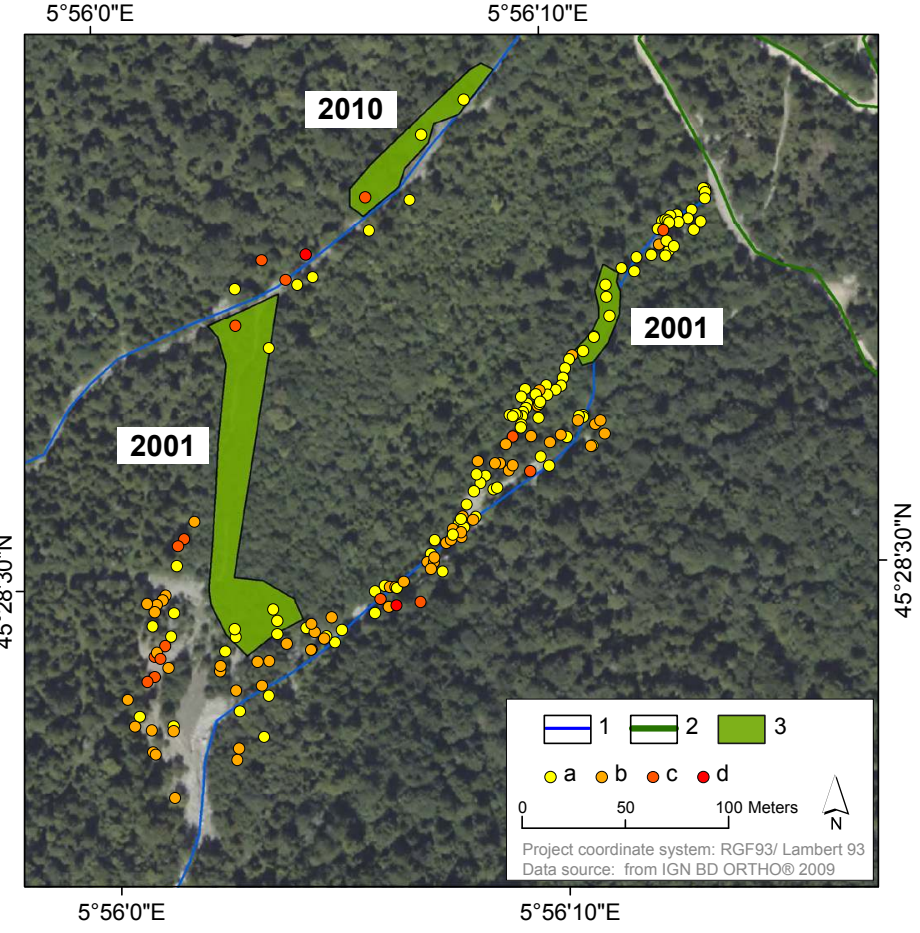

Fig. 5 - Age structure of sampled trees with datation of re-colonization patch of broadleaved trees.

1. Drainage network; 2. Forestry road; 3. Young broadleaved forest stand. Legend of the age structure: a. Between 10-25 years; b. Between 25-75 years; c. Between $75-$ 125 years; d. $<125$ years.

Fig. 5 - Cartographie de l'âge des arbres échantillonnés et datation des zones de recolonisation végétales de feuillus.

1. Réseau hydrographique; 2. Piste forestière; 3. Zone de recolonisation végétale de feuillus. Légende de l'âge des arbres échantillonnés : a. Entre 10-25 ans; b. Entre $25-75$ ans ; c. Entre 75-125 ans ; d. $<125$ ans.

recurrence interval is 4.66 years. To get more precision given to the average age structure and the number of sample, this study focused on a starting date at 1968 . Therefore 14 debris flows were reconstructed with a recurrence interval of 3.2 years and an activity peak in the 1980's.

\subsection{Spatial reconstruction and comparison with} orthophotographies analysis

The spatial distribution of trees affected by a same event allowed to determine the minimum spatial extent of a debris flow (Procter et al, 2012). The spatial extent of active sediment deposits has been reconstructed since 1956. It was also possible to identify temporal activities of each channel and usually confirmed the distribution of impacted trees. In 1956, the axial active channel flowed on the axial and eastern part consisted on the first step of cone deposit establishment. Furthermore, a secondary channel appeared on the northeastern part, at the same position of the current active channel. To link with the archivist works, an important debris flow was identified in 1950 that probably impact channels activities.

Impacted trees of the 14 debris flows since 1968 were mapped on the closest orthophotography to the event year (fig. 7). Since 1968, debris flows mainly flowed in the main axial channel. 1982, 1990, and 1996 orthophotographies showed a channel widening and 1991 seemed to be a debris flow key for the cone dynamic and spatial extent of debris flows. Northeastern channel was once again impacted but the frequency of the deviation became more and more important. From 2001, debris flow dynamics carried on with less 
impacted trees on both western and axial channels in favor of an improvement in the upper part. In the 2003 orthophotography, forest coverage decreased on the upper part, and northeastern secondary channel started to be visible. In 2006, incision dynamic on the eastern part clearly emphasized. Two intense debris flows in 2010 and 2012 didn't flow down to the confluence but deposited sediments close to the forest exploitation road and started to build down a new part of the cone. These two debris flows confirmed a recent disconnection of the western channel and upper part of the cone due to the incision of the eastern active channel.

\section{Discussion}

In this study a coupling methods of detailed geomorphic mapping, orthophotography and tree ring analyses enabled a better assessment of spatio-temporal reconstitution of past debris flow since 1968 and also completed debris flow frequency and channel dynamics of the depositional cone.

\subsection{Reconstitution of fan dynamics and debris flow spatial extent interpretation}

This study of 189 impacted trees highlights the occurrence of 14 debris flows between 1968 and 2013 and an estimation of 21 debris flows between 1915 and 2013. It linked the event spatial extent with the forested cone dynamics and especially relationships between major debris flows events with cone dynamics evolution. 4 mains steps dynamics were identified: (i) until 1970's: channel mobility on the downstream and central part of the cone establishment; (ii) from 1970 to 2000: debris flow activity in the axial channel, with filling of materials on the upper part of the cone; (iii) from 2001 to 2010: torrential activity turned on the west part; (iv) in 2010 flow direction of the northeast active channel have been modified to the forestry road with an upstream incision.

$10^{\text {th }}$ July 2013 a debris flow emphasized these dynamics evolution: the estimation of the incision was around $3 \mathrm{~m}$ in 5 years, the afforestation increased on the upper part, debris flow materials sprawl downstream both on the forestry road and on the left bank (on the older deposits). Through archivist information's and spatial extent of impacted trees, this study proposed a reconstitution of major debris flow spatial extent since 1982 (fig. 7). Impacted trees weren't sufficient before 1982 to precisely reconstruct any events. In terms of intensity and impacts on the fan dynamics, debris flows of 1982, 1991 and 2001 were identified as key debris flow.

\subsection{Comparison, perspectives and implication for natural hazard mitigation}

According to the literature, debris flow records could be reconstructed on the Holocene period by chronostratigraphy (Blair, 1999; Matthews et al., 2009) lichenometry (Helsen et al., 2002; Jomelli et al., 2002; Jomelli, 2013) and also by dendrogeomorphology. Bollschweiler and Stoffel (2007) succeeded to reconstruct past debris flow activity at Reuse de Saleinaz over 260 years and Stoffel et al. (2007) since 1566 on the forested cone of the Ritigraben torrent.

Due to some limits in the dendrogeomorphic analysis on this site, the reconstitution of debris flows was done for a recent past. In this young and steep highly active catchment, the probability of a pluriannual debris flow occurrence is very high. Moreover frequent and smaller debris flows were contained within the active channel and did not cause any damage to vegetation (Lopez-Saez et al., 2011). Conversely exceptionally large and devastating debris flows may destroy a part of the forest stand making impossible dendrogeomorphic analysis (Arbellay et al., 2010). The number of reconstructed debris flow events must to be seen as a minimum frequency and spatial extent past events. Analysis was also limited by the relatively young age of trees, average of 38 years old. Missing impacted trees and youth of the forest stand are regular limiting factors in dendrogeomorphic studies. To complete this lack, we determined the germination ages of homogeneous young broadleaved trees area. However, this limiting factor was partly offset by the use of an integrative approach. Bollschweiler et al. (2008) on the Grosse Grabe fan (Valais, Suisse) identified 49 debris flows combining an analysis of the age of the vegetal afforestation on materials to reconstruct the last event and growth disturbances analysis. Procter et al. $(2011,2012)$ used orthophotographies analysis to complete the reconstitution of the spatial extent of recent debris flows. To make up for this limits, diachronic orthophotography analysis helped

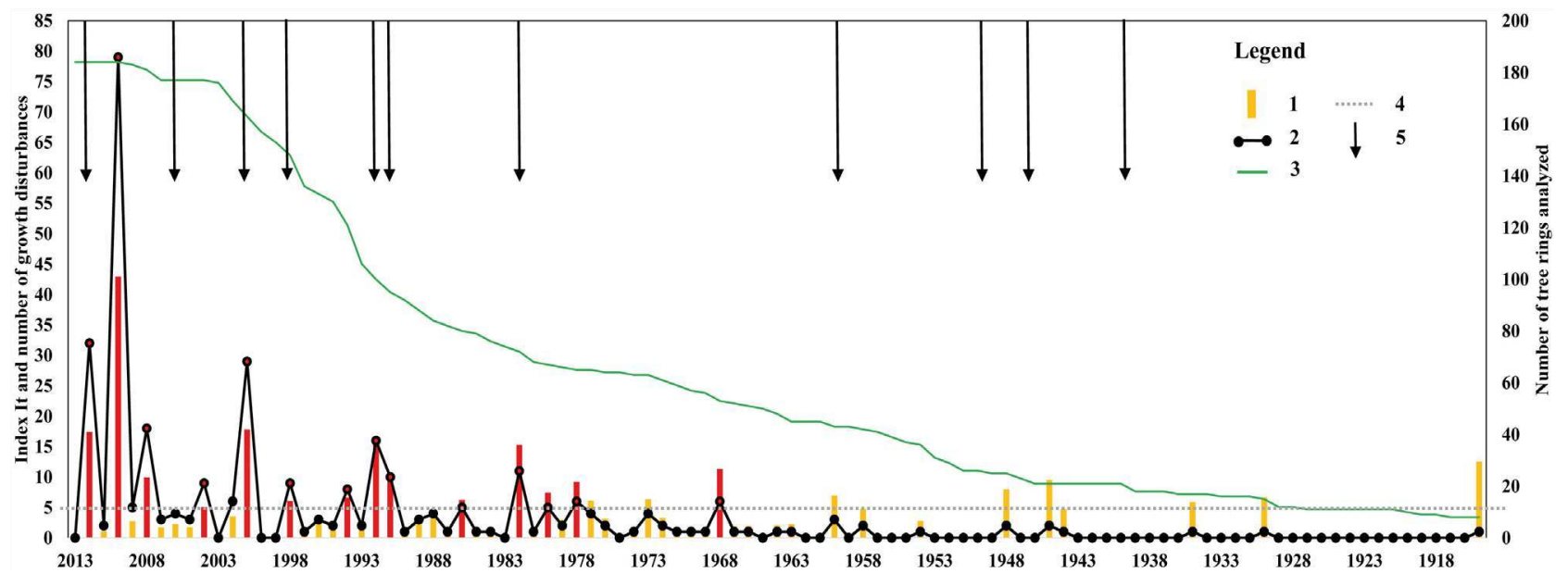

Fig. 6 - Debris flow frequency from historical archives and the reconstructed time series obtained with dendrogeomorphic methods.

Fig. 6 - Fréquence des laves torrentielles issues des archives historiques et de l'analyse dendrogéomorphologique.

1. Histogram of the It index (Lopez and Corona, 2015), the growth disturbance frequency per year; 2 . Number of growth disturbance per year; 3 .Number of tree ring analyzed per year; 4 . Threshold of Index $5 \%$ and 5 dates growth disturbances; 5 . Debris flows inventoried in the ONF Archives.

1. Histogramme de l'indice It (Lopez et Corona, 2015), la fréquence de perturbation de croissance par an; 2. Nombre de perturbation de croissance par an; 3. Nombre de cerne de croissance analysé par an; 4 . Seuil de l'indice It de $5 \%$ et de 5 perturbations de croissance datées; 5. Laves torrentielles inventoriées par les archives ONF. 

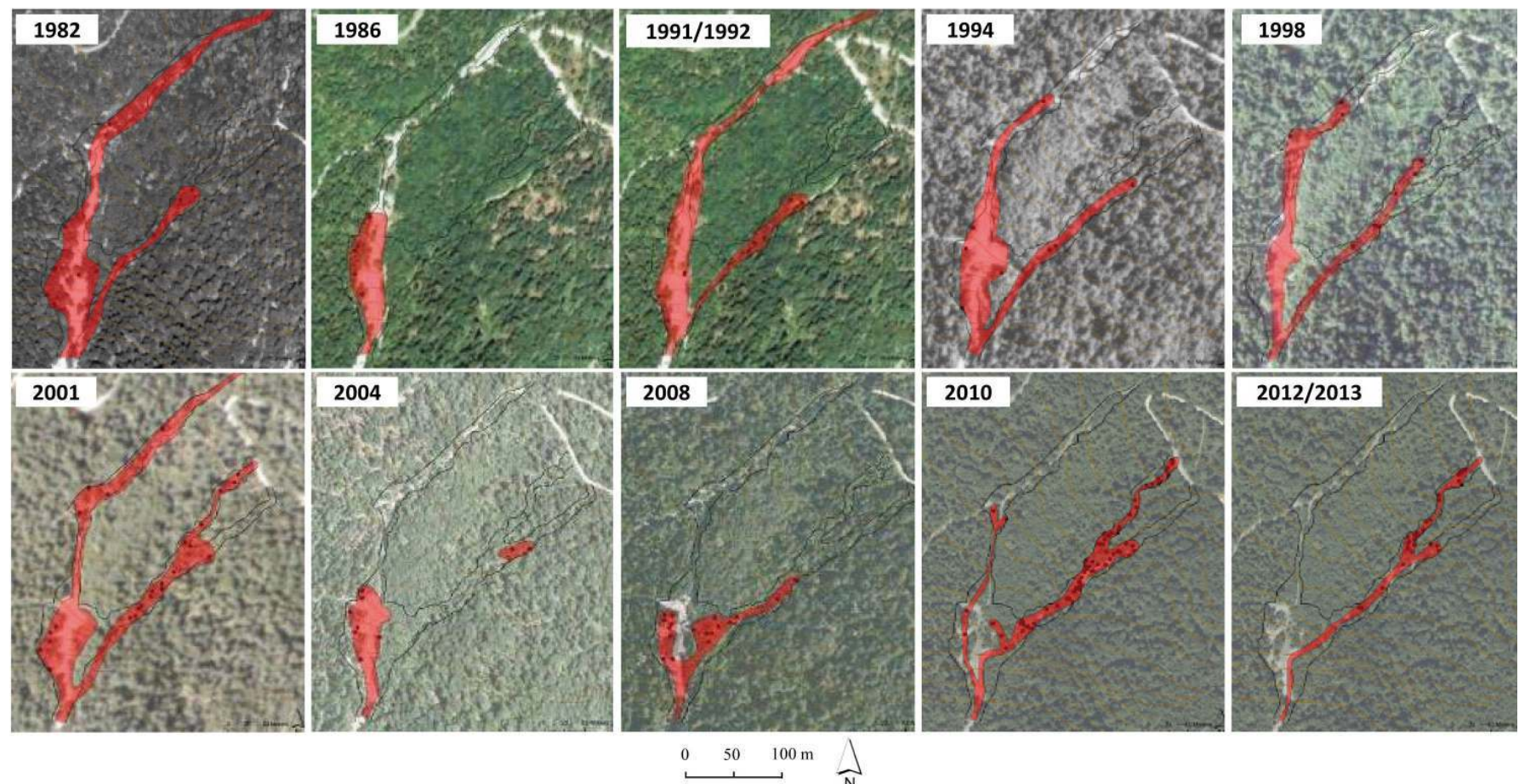

Fig. 7 - Hazard map of the minimum extension of past debris flows since 1982 reconstructed by orthophotography analysis, re-colonization forest stand analysis and dendrogeomorphology.

Fig. 7 - Carte d'aléa de l'extension minimum des laves torrentielles depuis 1982 réalisée à partir de l'analyse d’orthophotographies, de la recolonisation végétale et de la dendrogéomorphologie.

to identify some active or reactivated sectors and some drastic changes in channel mobility.

Otherwise the analysis of a long series of daily precipitation (Chavanne Météo France station, < $30 \mathrm{~km}$ from the study site) (fig. 8) shows no significant change in rainfall pattern linked to the phases highlighted. Torrential events are related to intense daily precipitation, but not systematically, and the opposite is not still true, even by looking at the hourly precipitation on the last decade (Chambéry Météo France station, $10 \mathrm{~km}$ from the study site). The catchment area, very small and with very steep slopes, responds mainly to intense and localized rainfall events. Thus, the comparison with the occurrence debris flow on the Manival torrent, $25 \mathrm{~km}$ away in the same massif (Lopez et al., 2011), shows a few same years in decades $80^{\prime}$ and 90', but the method is not precise enough to know if it results from the same rainfall event. However, the last reactivation period since the 1990s is common to both sites.

In the Ravin du Diable, the active phases are strongly related to sedimentary stocks available at the base of the Granier rockwall. The reactivation of the 1990s and the modification of the route of debris flow since 2000 are linked to the sedimentary saturation of the upper part of the cone and its incision, which releases sediments, and also in some attempts of artificial extraction of materials carried out on its middle part.

The implementation of a low cost integrative approach was the major contribution of this study to constitute an integrative approach to gain a comprehensive understanding of debris flow recurrence and relationships between key debris flows and channel mobility. Debris flows of the $20^{\text {th }}$ and $21^{\text {th }}$ century in the Ravin du Diable showed a frequency increasement. Owing to the youth of the forest stand, it was usual, but in context of global warming, these results may bring to light an increasement of the extreme climatic phenomena as it is validate in the IPCC (2013). Since the end of the Little Ice Age, it is possible that changing climatic conditions and the abundance of summer precipitation events impact debris flow activity and therefore frequency (Stoffel and Beniston, 2006). Pavlova et al. (2014) worked on the possible links between debris flow and climate conditions in the French Alps using different approaches. Furthermore, other studies focused on the estimation of sediment supply, of channel recharge rate to link with debris flow triggering. Debris flows or even avalanches, landslides are a major threat in the Alps, dendrogeomorphology allowed an expert assessment required for a better knowledge of geomorphic process in terms of frequency, magnitude and spatial extent.

\section{Conclusion}

Coupling methodology of dendrogeomorphology and orthophotography in Ravin du Diable allowed the identification of cone dynamism phases and geomorphic debris flow key. This results shows a recent pedagogic history of debris flows mobility and activity for the authorities.

Since the realization of this study, a massive rockfall $\left(100,000 \mathrm{~m}^{3}\right.$ on May 7, 2016) on the top of the Ravin du Diable put down a major cone just upstream to the torrential cone, constituting an important source of available materials. These materials were removed from the first significant rainfall, involving, on May 13, a debris flow which filled the artificial deposit zone built after the debris flow of 2013 and which propagated very beyond the previous known debris flow. The follow-up and the monitoring of torrential dynamics on the site since the rockfall is in progress.

\section{Acknowledgements}

The authors extend thanks to the Chapareillan municipality, the Natural Reserve of the Hauts de Chartreuse and the Forest National Office for providing historical data and authorized 


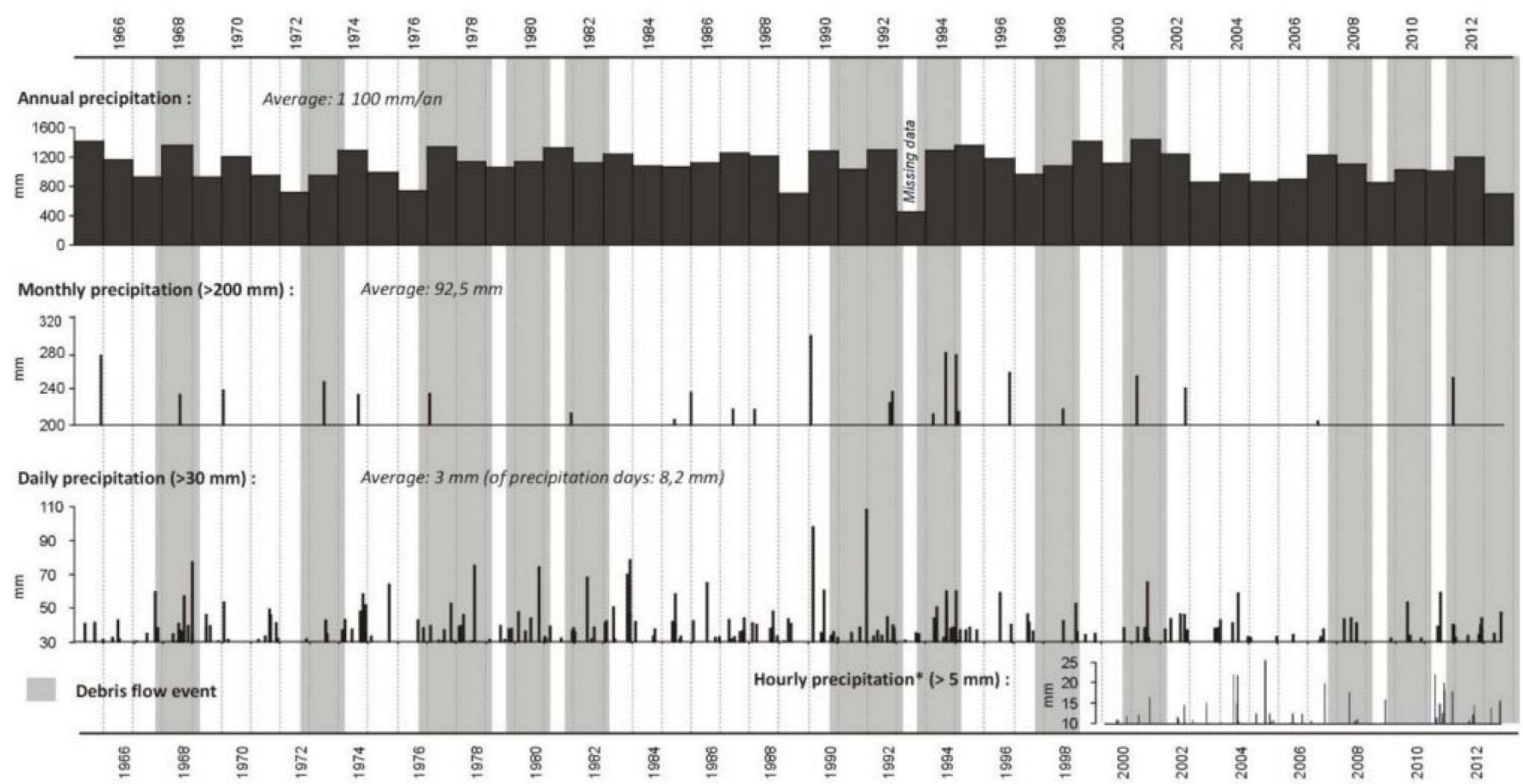

Fig. 8 - Rainfall in Chavanne station (1965-2013), Chambéry station (2000-2013), coupling with debris flow events inventoried in this study (source: Météo France).

Annual, monthly and daily rainfall measured at the Chavanne Station and hourly rainfall measured at the Chanbery station.

samples on the Glacières forest stand. The authors would like to thank Jérôme Lopez who initiated him to dendrogeomorphology methods and Julien Besson and Baptiste Launai for their assistance during the field work.

\section{References}

Alestalo J. (1971) - Dendrochronological interpretation of geomorphic processes. Fennia, 105, 1-140.

Arbellay E., Stoffel M., Bollschweiler M. (2010a) Dendrogeomorphic reconstruction of past debris flow activity using injured broad-leaved trees. Earth Surface Processes and Landforms 35, 399-406.

DOI : $10.1002 /$ esp. 1934

Arbellay E., Stoffel M., Bolschweiler M. (2010b) - Wood anatomical analysis of Alnus incana and Betula pendula injured by a debris flow event. Tree Physiology, 30, 1290-1298.

DOI : 10.1093/treephys/tpq065

Astrade L., Bégin Y. (1997) - Tree-ring response of Populus tremula L. and Quercus robur L. to recent spring floods of the Saône River, France. Ecoscience, 4 (2), 232-239.

DOI : $10.1080 / 11956860.1997 .11682400$

Astrade L., Stoffel M., Corona C., Lopez Saez J. (2012) L'utilisation des cernes de croissance des arbres pour l'étude des évènements et des changements morphologiques : intérêts, méthodes et apports des recherches alpines à la dendrogéomorphologie. Géomorphologie: Relief, Processus, Environnement, 18 (3): 295-316.

DOI : $10.4000 /$ geomorphologie.9925

Blair T.C. (1999) - Sedimentology of the debris-flow dominated Warm Spring Canyon alluvial fan, Death Valley, California. Sedimentology, 46, 941-957.

DOI : 10.1046/j.1365-3091.1999.00260.x
Fig. 8 - Précipitations à la Station de Chavanne (1965-2013), de Chambéry (2000-2013) croisées aux évènements de laves torrentielles recensés dans l'étude (source : Météo France).

Précipitations annuelles, mensuelles et journalières mesurées à la station de Chavanne et précipitations horaires mesurées à la station de Chambéry.

Bollschweiler M., Stoffel M. (2007) - Debris flows on forested cones - reconstruction and comparison of frequencies in two catchments in Val Ferret, Switzerland. Natural Hazards and Earth System Sciences, 7, 207-218.

DOI : $10.5194 /$ nhess-7-207-2007

Bollschweiler M., Stoffel M., Ehmisch M., Monbaron M. (2007) Reconstructing spatio-temporal patterns of debris flow activity using dendrogeomorphological methods, Geomorphology, 87, 337-351.

DOI : 10.1016/j.geomorph.2006.10.002

Bollschweiler M., Stoffel M., Schneuwly D.M. (2008) - Dynamics in debris-flow activity on a forested cone - a case study using different dendroecological approaches. Catena 72, 67-78.

DOI : $10.1016 /$ j.catena.2007.04.00

Bollschweiler M., Stoffel M. (2010) - Variations in debris-flow occurrence in an Alpine catchment - a reconstruction based on tree rings. Global and Planetary Change, 73, 186-192. DOI : 10.1016/j.gloplacha.2010.05.006

Bovis M.J., Jakob M. (1999) - The role of debris supply conditions in predicting debris flow activity. Earth Surface Processes and Landforms, 24, 1039-1054.

DOI : 10.1002/(SICI)1096-9837(199910)24:11<1039::AID-ESP29>3.0.CO;2-U

Bryant C.L., Butler D.R., Vitek J.D. (1989) - A statistical analysis of tree-ring dating in conjunction with snow avalanches: comparison of on-path versus off-path responses. Environmental Geology and Water Sciences, 14, 53-59.

DOI : $10.1007 / \mathrm{BF} 01740585$

Corona C., Rovéra G., Lopez Saez J., Stoffel M., Perfettini P. (2010) - Spatio-temporal reconstruction of snow avalanche activity using tree rings: Pierres Jean Jeanne avalanche talus, Massif de l'Oisans, France. Catena, 83, 107-118. DOI : 10.1016/j.catena.2010.08.004 
Corona C., Lopez Saez J., Rovéra G., Astrade L., Stoffel M., Berger F. (2011) - Validation d'une méthode de quantification des vitesses d'érosion sur marnes par dendrogéomorphologie, Draix, Alpes de Haute-Provence. Géomorphologie: relief, processus, environnement, 17 (1), 83-94.

DOI : 10.4000/geomorphologie.9254

Helsen M.M., Koop P.J.M., Van Steijn H. (2002) - Magnitudefrequency relationship for debris flows on the fan of the Chalance torrent, Valgaudemar (French Alps). Earth Surface Processes and Landforms, 27, 1299-1307.

DOI : 10.1002/esp.412

Hungr O., Evans S.G., Bovis M., Hutchinson J.N. (2001) - Review of classification of landslides of flow type. Environmental and Engineering Geoscience, VII, 221-238.

DOI : 10.2113/gseegeosci.7.3.221

Hupp C.R., Osterkamp W.R., Thornton J.L. (1984) Dendrogeomorphic evidence of debris flow frequency and magnitude at Mount Shasta, California. Environmental Geology and Water Sciences, 6 (2), 121-128.

IPCC (2013) - Climate Change 2013: The Physical Science Basis. Contribution of Working Group I to the Fifth Assessment Report of the Intergovernmental Panel on Climate Change. Cambridge University Press, Cambridge, United Kingdom and New York, NY, USA, $1535 \mathrm{p}$.

Jakob M., Jordan P. (2001) - Design flood estimates in mountain streams - the need for a geomorphic approach. Canadian Journal of Civil Engineering, 28 (3), 425-439.

DOI : $10.1139 / 101-010$

Jomelli V. (2013) - Lichenometric dating of debris flow deposits with an example in part of the French Alps. In Bollschweiler M., Stoffel M., Rudolf-Miklau F. (Eds.), Tracking Torrential Processes on Fans and Cones. Springer, Berlin, Heidelberg, New York, 211-224.

Jomelli V., Bertran P., Kunesch S. (2002) - Le cône de la Momie : un nouveau type de dépôt proglaciaire mis en place depuis la fin du Petit Age Glaciaire. Quaternaire, 13 (3), 257-263.

Lopez Saez J., Corona C. (2015) - La dendrogéomorphologie : Principes, Méthodes, Applications. Irstea, Grenoble, $52 \mathrm{p}$.

DOI : 10.13140/RG.2.1.2923.0560

Lopez Saez J., Corona C., Stoffel M., Gotteland A., Berger F., Liébault F. (2011) - Debris-flow activity in abandoned channels of the Manival torrent reconstructed with LiDAR and tree-ring data. Natural Hazards and Earth System Science, 11, 1247-1257. DOI : 10.5194/nhess-11-1247-2011

Matthews J.A., Dahl S.O., Dresser P.Q., Berrisford M.S., Lie O., Nesje A., Owen G. (2009) - Radiocarbon chronology of Holocene colluvial (debris-flow) events at Sletthamn, Jotunheimen, southern Norway: a window on the changing frequency of extreme climatic events and their landscape impact. The Holocene, 19, 1107-1129. DOI : $10.1177 / 0959683609344674$

May C.L., Gresswell R.E. (2004) - Spatial and temporal patterns of debris-flow deposition in the Oregon Coast Range, USA. Geomorphology, 57, 135-149.

DOI : $10.1016 /$ S0169-555X(03)00086-2

Mayer B., Stoffel M., Bollschweiler M., Hübl J., Rudolf-Miklau F. (2010) - Frequency and spread of debris floods on fans: a dendrogeomorphic case study from a dolomite catchment in the Austrian Alps. Geomorphology, 118, 199-206.

DOI : 10.1016/j.geomorph.2009.12.019
Mc Carthy D.P., Luckmann B.H. (1993) - Estimating ecesis for tree-ring dating of moraines: a comparative study from the Canadian Cordillera. Arctic, Antarctic, and Alpine Research, 25, 63-68.

DOI : $10.2307 / 1551482$

Pavlova I., Jomelli V., Brunstein D., Grancher D., Martin E., Deque M. (2014) - Debris Flow activity related to current climate conditions in the French Alps: a regional investigation. Geomorphology, 219, 248-259.

DOI : 10.1016/j.geomorph.2014.04.025

Procter E., Bollschweiler M., Stoffel M., Neumann M. (2011) - A regional reconstruction of debris-flow activity in the Northern Calcareous Alps, Austria. Geomorphology, 132, 41-50.

DOI : 10.1016/j.geomorph.2011.04.035

Procter E., Stoffel M., Schneuwly-Bollschweiler M., Neumann M. (2012) - Exploring debris-flow history and process dynamics using an integrative approach on a dolomitic cone in western Austria. Earth Surface Processes and Landforms, 37, 913-922.

DOI : 10.1002/esp.3207

Shroder J. (1978) - Dendrogeomorphological analysis of mass movement on Table Cliffs Plateau, Utah. Quaternary Research, 9, 168-185.

DOI : $10.1177 / 0309133313501107$

Schroder J.F. (1980) - Dendrogeomorphology: Review and new techniques of tree-ring dating. Progress in Physical Geography, 4 (2), 161-188.

Stefanini M. (2004) - Spatio-temporal analysis of a complex landslide in the northern Apennines (Italy) by means of dendrochronology. Geomorphology, 63, 191-202.

DOI : 10.1016/j.geomorph.2004.04.003

Stoffel M., Lièvre I., Conus D., Grichting M.A., Raetzo H., Gärtner H.W., Monbaron M. (2005) - 400 years of debris flow activity and triggering weather conditions: Ritigraben VS, Switzerland. Arctic, Antarctic and Alpine Research, 37 (3), 387-395.

DOI : 10.1657/1523-0430(2005)037[0387:YODAAT]2.0.CO;2

Stoffel M., Beniston M. (2006) - On the incidence of debris flows from the early Little Ice Age to a future greenhouse climate: a case study from the Swiss Alps. Geophysical Research Letters, 33, L16404.

DOI : 10.1029/2006GL026805

Stoffel M., Bollschweiler M. (2008) - Tree-ring analysis in natural hazards research - an overview. Natural Hazards and Earth System Science, $8,187-202$.

DOI : $10.5194 /$ nhess-8-187-2008

Stoffel M., Bollschweiller M., Leutwiler A., Aeby P. (2008) - Treering reconstruction of debris flow events leading to overbank sedimentation on the Illgraben cone, Valais Alps, Switzerland. The Open Geology Journal, 2, 18-29.

DOI : $10.7892 /$ boris. 85906

Stoffel M. (2010) - Magnitude-frequency relationships of debris flows - a case study based on field surveys and tree-ring records. Geomorphology, 116, 67-76.

DOI : 10.1016/j.geomorph.2009.10.009

Stoffel M., Wilford D.J. (2012) - Hydrogeomorphic processes and vegetation: disturbance, process histories, dependencies and interactions. Earth Surface Processes and Landforms, 37, 9-22. DOI : $10.1002 /$ esp. 2163

Stoffel M., Butler D.R., Corona C. (2013) - Mass movements and tree rings: A guide to dendrogeomorphic field sampling and dating. Geomorphology, 200, 106-120.

DOI : 10.1016/j.geomorph.2012.12.017 


\section{Version française abrégée}

Dans les Alpes et les Préalpes françaises, les laves torrentielles sont reconnues comme étant un des aléas les plus dévastateurs et comme le processus de transport le plus actif. Elles se produisent généralement dans des lits à fortes pentes où la recharge sédimentaire est abondante et facilement mobilisable.

Le Ravin du Diable se charge dans les gorges de la paroi du Mont Granier (Massif de la Chartreuse) avant de s'étaler dans la forêt, sur la piste forestière et sur la route départementale d'accès au cour du massif de la Chartreuse, formant ainsi un cône de déjection de versant (fig. 1). Ses laves torrentielles impactent régulièrement la hêtraie sapinière du cône rendant ce site propice au développement de méthodes dendrogéomorphologiques (Alestalo, 1971). Issue de la dendrochronologie, la dendrogéomorphologie se base sur le concept de Schroder $(1978,1980)$ «Process - Event - Response» pour reconstituer les processus géomorphologiques tels que les avalanches (Bryant et al., 1989 ; Corona et al., 2010), les inondations (Astrade et Bégin, 1997), les glissements de terrain (Stefanini, 2004 ; Lopez Saez et al., 2011) et les laves torrentielles, par la lecture de perturbations dans les cernes de croissance des arbres. Ces dernières décennies ont vu les études dendrogéomorphologiques sur les laves torrentielles se développer dans le but de reconstituer d'une part la fréquence, l'intensité d'évènements (Hupp et al., 1984; Mayet Gresswell, 2004; Stoffel et al., 2005 ; Bollschweiler et Stoffel, 2010, etc.) et d'autre part leurs extensions spatio-temporelles (Bollschweiler et al., 2007). L'utilisation plus récente d'orthophotographies et du Lidar a permis d'augmenter la résolution des reconstitutions. Ces archives environnementales sont aujourd'hui un moyen validé pour compléter les archives historiques, qui plus est dans ce contexte d'aléa récent encore mal connu où l'impact des laves torrentielles sur les infrastructures s'avère de plus en plus important.

L'objectif de cette étude est de mettre en place une approche intégrative couplant des méthodes de dendrogéomorphologie sur des résineux et feuillus avec une analyse diachronique d'orthophotographies dans le but de reconstituer (i) l'extension spatio-temporelle des laves torrentielles, (ii) la dynamique du cône forestier, (iii) l'extension spatiale des laves torrentielles clés dans la dynamique du site.

189 arbres ont été échantillonnés (fig. 3) selon le protocole issu de Bollschweiler et Stoffel (2007) et Arbellay et al. (2010a). 315 perturbations de croissance (tab. 1) ont permis d'identifier puis de spatialiser 14 laves torrentielles depuis 1968 dont 7 inconnues dans les archives (fig. 6) pour une période de retour de 3,2 ans. L'indice de fréquence "It Index » et le seuil des 5 arbres impactés par an (Lopez Saez, 2011 ; Lopez Saez et Corona, 2015) ont été utilisés pour valider ces évènements. Cependant la seule utilisation de l'It Index (Lopez Saez et Corona, 2015) couplée avec l'analyse spatiale des arbres impactés par année ont permis d'estimer l'occurrence de 21 laves torrentielles depuis 1915. L'âge moyen des 189 arbres échantillonnés est de 38,62 ans (fig. 5). Ce jeune âge du peuplement forestier est la conséquence du dynamisme du site, où un évènement majeur en détruisant une partie de la forêt réduit la quantité d'archives environnementales disponibles. Cela est cependant compensé par l'intermédiaire de l'analyse de la recolonisation végétale. Des zones de repeuplement forestier, principalement composées de jeunes feuillus, sont identifiées et datées afin d'en déduire l'âge de fixation de la forme et du dernier passage morphogène d'une lave torrentielle.

Le croisement avec l'analyse diachronique des chenaux ouverts (fig. 2) met en lumière 4 étapes de la dynamique du cône: (i) jusque dans les années 1970, les laves torrentielles se sont déposées dans la partie aval et centrale du cône, (ii) entre 1970 et 2000, l'activité torrentielle s'est produite dans la partie axiale remplissant de sédiments l'amont du cône, (iii) entre 2001 et 2010, la dynamique s'est accélérée avec le remplissage de matériel dans la partie ouest, (iv) depuis 2010, une incision en amont d'environ $3 \mathrm{~m}$ en 5 ans a fait basculer l'écoulement dans un paléochenal au nord-est. Les aménagements préalablement construits, comme le pont des Chartreux sous la route, sont contournés. De fait, les laves torrentielles s'étalent sur la piste forestière et la route départementale.

Des cartes d'aléas sont ainsi créées représentant l'extension minimale des laves torrentielles depuis 1982 (fig. 7) ainsi que la sélection de 3 laves torrentielles (1982, 1991 et 2001) comme évènements clés dans la dynamique du cône de déjection du ravin du Diable. Depuis la fin de l'étude, des aménagements ont été effectués pour ramener l'écoulement dans sa partie axiale. Mais un écroulement majeur (100000 $\mathrm{m}^{3}$ le 7 Mai 2016) dans les gorges de la paroi du Mont Granier a formé un tablier de charge sédimentaire mobilisable en amont du cône. Les précipitations du 13 Mai 2016 ont déclenché une importante lave torrentielle, qui s'est écoulée bien plus en aval que celles recensées dans l'étude, en remplissant la plage de dépôt récemment construite. 